\title{
Problems and Opportunities for the Development of Smart Specializations in Lower Silesia Region
}

\author{
Andrzej RASZKOWSKI \\ Wroclaw University of Economics, Wrocław, Poland \\ andrzej.raszkowski@ue.wroc.pl
}

\begin{abstract}
The presented study discusses problems related to smart specializations of Lower Silesia region, which represent one of the types of regional specializations. The introduction presents a short characteristic of Lower Silesia with particular emphasis on the regions' major advantages as well as crucial, unfavourable phenomena and processes occurring in the area. It is followed by characterizing Lower Silesian Smart Specializations (LSSS). The study was conducted using the subject literature query and the desk research methods. The purpose of the study is to present and analyse smart specializations in terms of potential problems, barriers and development opportunities. In conclusion it can be stated that one of the effects of projects implementation within the framework of LSSS areas should be the elimination of intraregional differences regarding the level of socio-economic development.
\end{abstract}

Keywords: Regional Development, Smart Specializations, Lower Silesia, Regional Specializations, Innovations.

\section{Introduction}

Lower Silesia region (Lower Silesian voivodship) represents one of the best economically developed areas of the country, significantly exceeding the country average regarding the gross domestic product value per capita in the regions and, moreover, it is highly ranked in terms of its investment attractiveness [22, 24].

The relatively well-developed transport infrastructure, favourable geographic location, extensive and diversified educational offer prepared by universities can be listed among the main strengths of the voivodship. Wrocław, the capital of the region, after Warsaw and Cracow, remains the largest academic centre in Poland regarding the number of students. The abundance of cultural potential, historical monuments, cultural events have to be highlighted too, since owing to them Wrocław was the European Capital of Culture in 2016. Moreover, it features exceptional natural values constituting the base for tourism sector development in Lower Silesian locations (e.g. Karpacz, Szklarska Poręba, Świeradów-Zdrój, Kudowa-Zdrój, Polanica-Zdrój). In addition, numerous economic sub-zones are functioning in the region, including the largest in Poland Wałbrzych Special Economic Zone "INVEST-PARK", offering additional development opportunities for investors. 
Apart from its unquestionable strengths, Lower Silesia is also characterized by unfavourable phenomena and processes, among which there are disproportions in the socio-economic development occurring in its area. One of the indicators showing the aforementioned disproportion is the unemployment rate by counties. In Wroclaw (a city with county rights) it amounts to $2.6 \%$ and remains one of the lowest in the country [1]. The lowest unemployment rate in the country has been, for many years, recorded in Poznan City, currently at the level of $1.7 \%$. The other extreme is represented by the Lower Silesian counties of Wałbrzych, Góra and Złotoryja (unemployment rate $15.8 \%, 15.9 \%, 16.6 \%$ respectively). Other problems include unevenness in the development of road infrastructure, housing stock, access to medical services, education. In addition, the region has to face the problem of population aging, labour emigration and delamination of remuneration structure. In the context of the above-mentioned characteristics, regional specializations should offer one of the methods for overcoming the existing weaknesses and threats as well as taking advantage of the emerging development opportunities. The activities carried out within the framework of regional specializations should be ultimately manifested in the life quality improvement of the local residents. Among the most important industrial sectors, in terms of production value, the following can be identified, according to the authors of the Strategic Framework ... [23] i.e. mining and quarrying, manufacturing automotive parts and accessories, manufacturing electronic products, manufacturing plastic and metal products and food production.

The concept of smart specializations became popular in the European terminology with regard to the programming process of the European cohesion policy in the 2014-2020 time horizon. The Europe 2020 strategy [2] is a pivotal document, representing a special developmental guide for the above-mentioned period. The more detailed presentation of problems related to smart specializations can be found in the Guide to Research and Innovation Strategies... (RIS 3) [15].

For the purposes of this paper it can be adopted that smart specializations represent one of the types of regional specializations which have much older origins and are firmly embedded in numerous theories and concepts related to the broadly understood regional development $[6,7,13,20,21]$.

The main purpose of the study is to present and analyse Lower Silesian smart specializations in the context of potential problems and development opportunities. Within the framework of added value the recommendations for the future of smart specializations in the analysed region are included at the end of the study.

\section{Smart specializations of Lower Silesia}

Among the Lower Silesian Smart Specializations (LSSS) the following are included: chemical and pharmaceutical industries; spatial mobility; high quality food; natural and secondary raw materials; manufacturing of machinery and equipment, processing of materials; information and communication technologies. Moreover, each of the aforementioned specializations covers a broader thematic sub-area related to a particular category. One of the reasons for defining LSSS was the concern for taking 
advantage of an opportunity to use the European funds, with particular reference to the Regional Operational Program of Lower Silesian Voivodship 2014-2020 [11], which, in turn, is one of the implementation tools for Lower Silesian Development Strategy 2020 [9]. The pragmatism of such approach is undisputable in the light of potential resources to be used, including the areas of innovation support (smart development, based on knowledge and innovation remains one of the priorities of the Europe 2020 strategy). It seems more founded to consider whether regional specializations, or rather their structure, should be limited to sectors, thematic areas, offering an occasional opportunity for obtaining public support. The number of selected LSSS does not differ significantly from the number of choices made in other voivodships, hence one can assume that it approximates the average. A solution to be considered in this situation is to develop the so-called "reserve list" including the specializations presenting a noticeable development potential, which are not critical at a given moment.

LSSS identification process was based on the recommendations presented in RIS 3, where the area of smart specializations is described with reference to two dimensions of the phenomena occurring in the region. Economic specialization is taken into account, which is manifested by the presence of sectors presenting above average results. Generally, it refers to manufacturing, employment rate, investments generating GVA, i.e. the value of all products and services produced by all regional entities less production costs, representing the increase in the value of goods over a given period. The second dimension is the scientific and technological specialization, analysed in terms of scientific and patent activity in specific fields and implementation potentials in technological areas. Smart specializations should represent a natural effect of these two dimensions penetration along with catalysing their competitive advantages.

\section{Selected problems and opportunities for the development of Lower Silesian smart specializations}

An attempt to characterize and highlight the main issues and opportunities affecting LSSS development in the coming years was made in the next part of the study. Knowledge of these issues will allow undertaking appropriate actions to take advantage of the emerging opportunities and also to minimize and overcome the existing barriers.

Table 1. Problems, barriers for the development of Lower Silesian smart specializations [5, 9, $10,16,23]$.

\begin{tabular}{ll}
\hline $\begin{array}{l}\text { Problem, } \\
\text { barrier }\end{array}$ & Justification \\
\hline $\begin{array}{l}\text { Increasing } \\
\text { competition from } \\
\text { other regions }\end{array}$ & $\begin{array}{l}\text { Despite its undisputable strengths and development potentials, } \\
\text { the region of Lower Silesia is exposed to competition from other } \\
\text { territorial units, both domestic and foreign. The activities of } \\
\text { competition, especially in terms of attracting new and }\end{array}$ \\
\hline
\end{tabular}


maintaining the existing investors, is increasing. Among the other fields of competition the following can be listed: attracting tourists and hikers, gaining new residents or students. A separate category is competing for the European funds. Some of the funds allocated to Poland for the 2014-2020 programming period have been divided territorially (allocated to specific voivodships), nevertheless, there is still a significant pool to be applied for through national competitions or joint cross-border initiatives.

The subareas of LSSS constitute the set of ambitious and innovative initiatives, largely geared towards innovative technologies. The advancing consumer awareness and their Increasing level of increasing requirements can turn out a potential problem in the consumer way of their effective implementation. This applies, in awareness and particular, to chemical and pharmaceutical industries, high requirements quality food as well as information and communication technologies. In order to keep up with rapidly changing preferences and quality requirements, the offer has to be continuously improved and upgraded. our offerings. Failure to do so may result in reduced production or market fallout.

In order to compete in innovative technology sectors both high initial costs and high barriers of market entry have to to be expected. It is not just a coincidence that a significant part of

High barriers of market entry

Instability of legal regulations costs in the region Lower Silesian enterprises, also from innovative industries, operates on a subcontracting basis by supplying components for technologically advanced products. Leading on innovative markets is difficult, however, it does not mean that one has to give up trying. IT technology should offer a relatively high potential in this area.

From the very beginning of a free market economy after 1989 entrepreneurs have been identifying difficulties in running a business related to the instability of legal regulations. It should be observed that during the discussed period numerous attempts were made to simplify and facilitate due procedures. The balance of legal changes can be considered positive, nevertheless there are still areas requiring improvements to be made (e.g. interpretation of tax regulations, time needed to set up a business, protection of intellectual property).

For many years Polish regions, including Lower Silesia, have been competing for investors and often becoming successful through low labour costs and relatively satisfactory productivity supported by the quality of human capital. The period of LSSS functioning is a good moment to move towards product/service quality, advanced technologies or product brand based competition. The other side of the coin is the expected increase 
in wages in the region or, in a broader perspective, the increase in labour costs. This situation may have some impact on the competitiveness and functioning of the entities representing LSSS.

The occurring crises and economic fluctuations are extremely difficult to predict. The best example of such situation is the latest global economic crisis dating back to 2007, having its origins, in simplified terms, in the US mortgage market. It can

Fluctuations of economic conditions be adopted that a significant part of sectors identified in LSSS is quite sensitive to economic turbulences and business fluctuations. The best remedy for potential problems is to take into account potential crisis situations in the business plans of individual entities. Scenario oriented planning, developing alternative operating strategies, flexibility and fast reaction to changes occurring in the milieu can turn out helpful in such situation.

The processes of social stratification can become an intermediary barrier in the development of LSSS. Despite the undeniable socio-economic development of the region, the stratification scale has not improved radically. Better life quality in cities is not followed by the proportional improvement of the

Processes of social existence standards in rural areas and small towns. The stratification exception here are the EU subsidies dedicated to the agricultural sector, which resulted in real, positive changes. Similar phenomena can be observed in relation to differences in interregional development of the country. The social stratification itself results in a number of unfavourable consequences (e.g. social exclusion, poverty, pathologies, crime, inheriting unemployment, reduced social activity).

The process of raw materials depletion mostly involves the LSSS area of natural and secondary raw materials. It constitutes a development barrier the consequences of which can be Resources experienced in several or even a dozen or so years. At present it depletion is justified to take up specific actions anticipating future threats. A long-term strategy of company development, the possibility of rebranding, supporting business activity by sector diversification represent the examples of proper directions in this field.

One of the manifestations of global economy is the ease of business activity relocation on an unprecedented scale. This

Moving business phenomenon also refers to the region of Lower Silesia. Some to countries with entities, mostly the foreign ones, while initiating their activities lower production in the region, assume in advance a certain period of operation, costs e.g. taking advantage of preferential conditions in the start-up period. This phenomenon cannot be completely eliminated, however, with respect to LSSS specific remedies, resulting from 


\begin{tabular}{|c|c|}
\hline & $\begin{array}{l}\text { the regional conditions, can be taken. The entities entering LSSS } \\
\text { areas, excluding manufacturing cost, report the demand for high } \\
\text { quality human capital, expect political and legal stability, } \\
\text { whereas some rely on a large sales market. }\end{array}$ \\
\hline $\begin{array}{l}\text { Outflow of } \\
\text { qualified staff to } \\
\text { other labour } \\
\text { markets }\end{array}$ & $\begin{array}{l}\text { Flexibility in approaching the workplace, changing it due to the } \\
\text { desire for professional and personal development represent yet } \\
\text { another sign of the times. The loss of valuable employees, } \\
\text { especially for the industries operating in innovative areas is } \\
\text { a certain development barrier. As a remedy, LSSS representing } \\
\text { entities may offer attractive remuneration systems (material and } \\
\text { non-material), a relatively high employment stability and } \\
\text { indicate the development potential of both the industry and the } \\
\text { region. }\end{array}$ \\
\hline $\begin{array}{l}\text { Digital exclusion } \\
\text { of some part of the } \\
\text { society (senior } \\
\text { citizens) }\end{array}$ & $\begin{array}{l}\text { This particular barrier applies primarily to the LSSS area of } \\
\text { information and communication technologies (ICTs). The } \\
\text { assumed, innovative solutions should be as extensive as } \\
\text { possible. Apart from reducing the quality of regional human } \\
\text { capital, the digital exclusion process will narrow down the } \\
\text { potential market for innovative products and services. The } \\
\text { effective education programs and training systems represent the } \\
\text { key for improvement in this respect. }\end{array}$ \\
\hline $\begin{array}{l}\text { Deficiencies in } \\
\text { establishing proper } \\
\text { climate for } \\
\text { entrepreneurship }\end{array}$ & $\begin{array}{l}\text { The identified development barrier is of general nature and } \\
\text { refers to all LSSS areas. The regional climate for business } \\
\text { facilitates LSSS functioning as well as other actors contributing } \\
\text { to the regional reality. Establishing such climate should be } \\
\text { initiated in the early years of school education by attracting } \\
\text { more attention to economic subjects, by pointing to good } \\
\text { examples and success stories of entrepreneurial individuals. }\end{array}$ \\
\hline $\begin{array}{l}\text { Short life cycle of } \\
\text { innovative } \\
\text { products and } \\
\text { services }\end{array}$ & $\begin{array}{l}\text { It can be adopted that in today's competitive milieu the product } \\
\text { life cycle is shortened. The simplest solution in such situation is } \\
\text { launching a new product or introducing significant } \\
\text { improvements to the existing ones. In both cases these are cost- } \\
\text { generating activities. Developmental barriers may affect } \\
\text { practically all LSSS areas. }\end{array}$ \\
\hline $\begin{array}{l}\text { Higher prices of } \\
\text { technologically } \\
\text { advanced products }\end{array}$ & $\begin{array}{l}\text { Products and services, planned improvements within LSSS are } \\
\text { based on advanced, innovative solutions. The final price offer } \\
\text { may act as a development barrier (addressed to either a business } \\
\text { or an individual client). The following factors are important: } \\
\text { absorptiveness of the regional market, the level of regional } \\
\text { community wealth, the allocation of production to either } \\
\text { domestic or foreign markets. }\end{array}$ \\
\hline
\end{tabular}

The list of identified problems is relatively extensive and does not represent a closed catalogue. It can also become a source for discussion about the future of regional development and the functioning of LSSS. Not all of the listed barriers are of the 
same significance. The most important ones are as follows: increased competition from other regions, the outflow of qualified personnel to other labour markets and the increasing labour costs in the region. The list of potential barriers and problems can change and evolve over time, therefore it is of great importance to carry out permanent monitoring of LSSS implementation and perform proper diagnosis of the trends occurring in the milieu. In addition, the opinions of entities operating within each sub-area can be used.

Table 2. Opportunities for the development of Lower Silesian smart specializations $[3,4,8,9$, $10,12,14,17,18,19,23]$.

\begin{tabular}{|c|c|}
\hline $\mathrm{Op}$ & cation \\
\hline $\begin{array}{l}\text { The EU funds from } \\
\text { the new financial } \\
\text { perspective }\end{array}$ & $\begin{array}{l}\text { The significance of the EU funds for LSSS from 2014-2020 } \\
\text { financial perspective has already been mentioned in the earlier } \\
\text { part of the study. The Regional Operational Program for } \\
\text { Lower Silesian Voivodship 2014-2020 is important, but also } \\
\text { other national programs (e.g. Smart Development Operational } \\
\text { Program) offer extensive possibilities. The effective use of } \\
\text { available resources will be of crucial importance as well as } \\
\text { funding projects of particular significance for the dynamics of } \\
\text { LSSS development. }\end{array}$ \\
\hline $\begin{array}{l}\text { Adjusting university } \\
\text { courses to labour } \\
\text { market requirements }\end{array}$ & $\begin{array}{l}\text { One of the important initiatives, within the framework of } \\
\text { which the functioning of LSSS can be realistically supported, } \\
\text { is meeting the expectations of entrepreneurs by pursuing } \\
\text { specific courses at regional universities. The examples include: } \\
\text { mathematics, chemistry, computer technology, biotechnology, } \\
\text { design, construction, mechanics and machine construction, } \\
\text { automation and robotics, mechatronics, materials engineering, } \\
\text { environmental engineering. }\end{array}$ \\
\hline $\begin{array}{l}\text { ing demand } \\
\text { vative } \\
\text { s/services }\end{array}$ & $\begin{array}{l}\text { The assumption can be adopted that, in general terms, the } \\
\text { demand for innovative products and services is increasing. } \\
\text { Consumers are curious of new solutions, look for offers which } \\
\text { improve their functioning in both professional and personal } \\
\text { environment. Implementing innovations (product, process, } \\
\text { organization and marketing specific) by enterprises is one of } \\
\text { the responses to dynamic changes taking place in the market } \\
\text { environment. LSSS areas can serve as centres of innovation } \\
\text { and advanced technologies provision in the region. }\end{array}$ \\
\hline $\begin{array}{l}\text { The development of } \\
\text { environmentally } \\
\text { friendly technologies }\end{array}$ & $\begin{array}{l}\text { Projects related to the broadly understood environmental } \\
\text { protection are important from the perspective of Lower Silesia } \\
\text { region sustainable development. In the coming years, } \\
\text { significant public resources, including the EU ones, e.g. the } \\
\text { Infrastructure and Environment Operational Program, will be } \\
\text { dedicated to the implementation of projects in this area } \\
\text { (including projects covering Renewable Energy Sources). }\end{array}$ \\
\hline
\end{tabular}


LSSS areas representing the potential beneficiaries and creators of environmentally-friendly solutions are as follows: spatial mobility, high quality food, natural and secondary resources, information and communication technologies (smart buildings and smart cities).

Innovative products, manufactured using advanced technologies are usually characterized by a higher price, at Increased wealth of least in the initial stages of their marketing. The success of part of the society LSSS depends partly on the level of regional residents' wealth (urban areas) and the dynamics of internal demand. It should be observed that wages have been increasing steadily over the years, with particular emphasis on urban areas.

The population aging process is essentially a negative phenomenon and also a progressive one in the predictable time horizon. It covers practically all regions of the country, including Lower Silesia. The Total Fertility Rate (TFR) in the region is currently at a very low level, oscillating around 1,3 Population aging (the replacement of generations occurs at the value of 2,1). This unfavourable phenomenon, however, simultaneously creates development opportunities for some of LSSS areas: chemical and pharmaceutical industries, high quality food, information and communication technologies (support for senior citizens).

The chance refers, in particular, to LSSS area of high quality food. Lower Silesia is truly abundant in local and regional Increased interest in products. Their proper exposure and promotion is the key to local and regional success. A local/regional product is understood as a product or products service that the given area residents identify themselves with, which is produced in a non-mass and environmentally friendly way, from the locally/regionally available materials.

Cluster initiatives, assuming their endogenous nature, can have positive impact on LSSS functioning. Clusters are responsible for e.g. the development of a scientific infrastructure to be The emerging used by entrepreneurs, human capital quality strengthening, regional cluster knowledge dissemination and generating innovations resulting initiatives from spatial proximity, attractive labour market development, creating innovation oriented culture and numerous benefits for entrepreneurs resulting from cooperation within the framework of a cluster.

Start-ups, i.e. in simplified terms, innovative business ventures are inherently highly risky. However, it is worth trying to The development of organize them, as the selected initiatives can turn into serious sector start-ups businesses. Innovation is included in the start-up business model, thus being a natural support for the sectors cantered around LSSS. Another advantage of start-ups are large public 


\begin{tabular}{ll}
\hline & funds allocated for their support and development. \\
\hline & An attractive labour market created by LSSS actors is a natural \\
& magnet for both domestic and foreign experts. In addition, the \\
The possibility of & region of Lower Silesia itself has many advantages, making it \\
attracting specialists & an interesting place to live. Apart from the purely occupational \\
to the region & aspects, the opportunities for spending leisure time are also \\
& important. At this point one can refer to the so-called \\
& "manager's wife effect". \\
\hline & The development of e-commerce in the region has an \\
& increasing tendency, just as in the entire country. Its \\
& continuously high growth potential represents its significant \\
& opportunity. The share of e-commerce in total trade \\
transactions is definitely lower than the standards in this & respect present in Western Europe or the United States. Just \\
E-commerce & like e.g. in case of paying with credit cards. The following \\
development & LSSS representatives should be most interested in the \\
development of e-commerce: chemical and pharmaceutical & industry, high quality food, information and communication \\
technologies. & The treng
\end{tabular}

The trend focused on healthy and active lifestyle remains an opportunity for regional specialization related to high quality

The promotion of food. Promoting healthy lifestyle and physical condition healthy lifestyle improvement is already firmly rooted in media coverage, numerous organized events, regardless of the obvious support offered by the medical environment. Food, in this situation, represents an indispensable part of this phenomenon.

The development of interdisciplinary research projects cannot be referred to as the current fashion, such projects have existed since the beginning of science. Today, they are characterized The implementation by two key elements: their scale and greater opportunities in of interdisciplinary research projects collecting funds for their implementation. Interdisciplinary character is beneficial for the development of all LSSS due to: a fresh look at research problems, the use of functional benchmarking, the transfer of knowledge and skills, the involvement of a wider group of researchers.

Conducting activities within Special Economic Zones is yet another development opportunity for LSSS. Three sub-zones

The functioning of are functioning in Lower Silesian Voivodship: Kamienna Góra Special Economic Zones Special Economic Zone of Small Entrepreneurship, Legnica Special Economic Zone and the largest in the country Wałbrzych Special Economic Zone. Preferential conditions for business activity refer, in particular, to the system of tax reliefs and operating in the specially prepared investment area.

Increased activity of The activity of non-governmental organizations can be NGO sector beneficial for all LSSS areas. The effectiveness of NGOs is 
a manifestation of the desirable process aimed at higher involvement of regional communities. Moreover, NGOs can also remain partners in implementing joint, innovative projects. In the new financial perspective of the European Union they have broader opportunities in applying for aid.

Particular attention should be paid to the following of the listed opportunities: European funds from the new financial perspective, the growing demand for innovative products/services, the development of sector start-ups, or wider implementation of interdisciplinary research projects.

\section{Summary and conclusion}

In terms of barriers and opportunities, identified in the study and related to the development of smart specializations in Lower Silesia, the following conclusions and recommendations can be put forward:

- regional specific features should be supported within the framework of the conducted regional policy, specialization in a defined, narrow area offers possibilities for developing real competitive advantages. The ultimate number of specializations should not be over extensive. The diversification of activities in too many areas can lead to failure in achieving the intended effects in any of them,

- one of major effects resulting from projects' implementation within LSSS areas should be the reduction of intraregional differences in the level of socio-economic development,

- the presented problems and opportunities for LSSS development are intended as recommendations, they send out a signal for all persons and entities involved in the development of the region to undertake actions aimed at overcoming problems and taking advantage of the emerging opportunities,

- Lower Silesia region has many potentials and resources which can contribute to its development. The existing situation is far better than in case of most other regions in the country (e.g. so-called "Eastern Poland"). In this light, the choice of smart specializations represents an element of the new doctrine of regional development, coexisting with the new approach to the development of the European regional space. At the same time, it will be possible to analyse and assess the effects of this approach in the years to come.

Doing business, conducting science and technology activities within the Lower Silesian Smart Specializations can, indisputably, contribute to socio-economic development of the region in the coming years. The potential success is determined e.g. by the efficient use of the EU funds, closer co-operation between science and business, performing activities aimed at activating potentials and the creativity of regional community. The process of LSSS development stimulation should cover the largest possible number of users and creators of the regional space (e.g. entrepreneurs, 
local authorities, universities, cultural institutions, business environment institutions, non-governmental organizations).

Smart specializations should be based on regional development potentials, mainly the innovative and economic ones. Meanwhile, it has to be remembered that developing competitive advantage in both national and international dimension should result from these specializations in the future.

\section{References}

1. Central Statistical Office: Registered unemployed I-II quarter 2017. Statistical Information and Elaboration, Warsaw (2017).

2. European Commission: Europe 2020. A strategy for smart, sustainable and inclusive growth. Communication from the Commission. Brussels (2010).

3. Florida R.: The Rise of the Creative Class: and How It's Transforming Work, Leisure, Community and Everyday Life. Basic Books, New York (2002).

4. Głuszczuk, D., Raszkowski, A.: Statistical presentation of innovation activities in enterprises - Oslo Manual 2005 proposals and the Central Statistical Office practice. In: Löster, T., Pavelka, T., Macáková L. (eds.) The 10th International Days of Statistics and Economics. Conference Proceedings, September 08-10, pp. 472-481. Melandrium, Prague (2016).

5. Głuszczuk, D., Raszkowski, A.: Unemployment rate in the perspective of labour force survey and national employment offices - measurement problem based on the example of Polish regions. In: Löster, T., Pavelka, T., Macáková L. (eds.) The 9th International Days of Statistics and Economics. Conference Proceedings, September 10-12, pp. 467-476. Melandrium, Prague (2015).

6. Grosse, T.: Przegląd koncepcji teoretycznych rozwoju regionalnego. Studia Regionalne I Lokalne 1(8), 25-48 (2017).

7. Klasik, A.: The Culture Sector and Creative Industries as a New Foundation of Development of Large Cities and Urban Agglomerations. In: Klasik, A. (ed.) The Cities and Agglomerations Development Based on the Culture Sector and Creative Industries. KPZK PAN, Warsaw (2011).

8. Kotler, P., Asplund, C., Rein I., Haider D.: Marketing places Europe. How to attract investments, industries, residents and visitors to cities, communities, regions and nations in Europe. Financial Times Prentice Hall, London (1999).

9. Lower Silesian Marshal Office: Regional Development Strategy of the Voivodeship of Lower Silesia 2020. Wrocław (2013).

10. Lower Silesian Marshal Office: Regional Innovation Strategy for Lower Silesian Voivodeship for years 2011-2020. Wrocław (2011).

11. Lower Silesian Marshal Office: Regional Operational Programme for the Lower Silesian Voivodeship 2014-2020. Wrocław (2014).

12. Porter, M.: Competitive advantage. Creating and sustaining superior performance. The Free Press, Simon and Schuster, New York (1998).

13. Porter, M.: On Competition, Updated and Expanded Edition. Harvard Business Review Press, Boston (2008).

14. Przybyła, K., Kachniarz, M.: The Impact of Administrative Reform on the Central Functions of Larger Polish Cities. Journal of Economic Issues 51(3), 843-862 (2017).

15. Publications Office of the European Union: Guide to Research and Innovation Strategies for Smart Specialisations (RIS 3). Luxembourg (2012). 
16. Raszkowski, A., Głuszczuk, D.: Regional creativity factors. Towards new dimensions of regional development. In: Löster, T., Pavelka, T., Macáková L. (eds.) The 9th International Days of Statistics and Economics. Conference Proceedings, September 10-12, pp. 13751385. Melandrium, Prague (2015).

17. Raszkowski, A.: Nowe trendy w marketingu miejsc. In: Korenik, S., Dybała A. (red.) Przestrzeń a rozwój. PN UE nr 241, Wydawnictwo Uniwersytetu Ekonomicznego we Wrocławiu, Wrocław (2011).

18. Raszkowski, A.: Place marketing in the process of territorial identity creation and strengthening. Journal of European Economy 13(2), 193-204 (2014).

19. Raszkowski, A.: Towards local development based on territorial identity. In: Hlaváček, P., Olšová, P. (eds.) Regional Economy and Policy. Territories and Cities. Jan Evangelista Purkyně University in Ústí nad Labem, Ústí nad Labem (2014).

20. Stimson, R., Stough, R., Roberts B.: Regional Economic Development. Analysis and Planning Strategy. Springer, Heidelberg (2006).

21. Strzelecki, Z.: Polityka regionalna. W: Strzelecki, Z. (red.) Gospodarka regionalna i lokalna. Wydawnictwo Naukowe PWN, Warszawa (2008).

22. The Gdańsk Institute for Market Economics, Konrad-Adenauer-Stiftung Poland Office: Investment attractiveness of voivodships and subregions in Poland 2016. Szultka S. (ed.), Gdańsk (2016).

23. Urząd Marszałkowski Województwa Dolnośląskiego: Ramy strategiczne na rzecz inteligentnych specjalizacji Dolnego Śląska. Załącznik do RSI dla Województwa Dolnośląskiego 2011-2020. Wrocław (2015).

24. Warsaw School of Economics: Regional investment attractiveness 2016. Report prepared for the Polish Information and Foreign Investment Agency at the Institute of Enterprise, Warsaw (2016). 